\title{
Early appearance of serum proteins in dog bile
}

\author{
Kurt Weigand* \\ Department of Medicine, Stauferklinik, Mutlangen, Teaching Hospital of the University of Ulm, Germany
}

\begin{abstract}
Background and aim: The mechanism of secretion of plasma proteins into bile has been shown for rats but not for higher animals and for humans. Since dogs are a much better model for human beings, the experiments were performed in dogs.
\end{abstract}

Methods: The radioactive precursor amino acid leucine was injected into the dog vein and the increase of free radioactivity and of the protein bound radioactivity in serum and in bile was followed.

Results: The secretion time for plasma proteins in the dog was 8-20 minutes. The secretion of radioactive proteins into bile showed a smaller peak after 20 minutes and a steep increase after 45 minutes.

Conclusion: The biphasic appearance of radioactive proteins in bile indicates that the majority of bile proteins are derived from serum, a small amount, however, is secreted by hepatocytes directly into the bile.

\section{Introduction}

It has been demonstrated that the quantitatively most important proteins in bile, albumin and IgA [1], are transferred from plasma into bile [2]. However, it is unknown whether hepatocytes can secrete these proteins also directly into bile. If proteins are exclusively transferred from plasma into bile, radioactive proteins should not be detectible in bile earlier than in plasma after IV injection of a radioactive precursor amino acid. To determine if hepatocytes secrete newly synthesized proteins into bile directly, we studied the secretion of radioactively labeled proteins into bile and into plasma in the dog. The experiments were performed with dogs since it has been shown that for the study of the transport of IgA from plasma to bile dogs are a suitable model for humans in contrast to rats or rabbits [3].

\section{Methods}

The experiments were performed in two not anesthetized female boxer dogs, weighing 20 (24) kg. Both dogs were equipped with a permanent Thomas cannula. A bile duct catheter was placed through the Thomas cannula and bile was collected at two minutes intervals. Bile flow was kept constant by infusion of $20 \mu \mathrm{mol}$ taurocholate per minute. After i.v. injection of $250 \mu \mathrm{Ci} 1$-14-C-leucine ( $59 \mathrm{mCi} / \mathrm{mmol})$ plasma samples were drawn every 2 minutes. Protein radioactivity was measured according to Mans and Novelli [4]. Protein was measured by the method of Lowry [5]. Bile acids were measured enzymatically [6]. Dogs were kept and treated strictly according to the guidelines of the health department of the city of Berne, Switzerland.

\section{Results}

After injection of $250 \mu \mathrm{Ci} 1$-14-C-leucine $(59 \mathrm{mCi} / \mathrm{mmol})$ it decreased rapidly in serum (Figure 1 and 2). Radioactively labeled proteins in serum were detectable after 10 to 14 minutes and increased exponentially. In bile non protein bound radioactivity appeared already after 6 minutes in $\operatorname{dog} 2$ (Figure 2), reaching a peak after 15 minutes.
In dog 1 non protein radioactivity appeared after 12 minutes, reaching a peak after 25 minutes (Figure 1). Radioactively labelled proteins in bile appeared after 10 and 14 minutes and increased rapidly with a peak after 20 or 30 minutes, respectively (Figure 3). After 45 minutes the radioactively labeled proteins in bile increased in parallel to the radioactive proteins in serum (Figure 3 ). Biliary protein excretion with about $2 \mathrm{mg} / \mathrm{min}$, remained constant during the experimental period, whereas the specific radioactivity of bile proteins increased by time (Figure 4 and 5). Bile flow with about $400 \mu \mathrm{l} / \mathrm{min}$, bile acid excretion with about $60 \mu \mathrm{mol} / \mathrm{min}$ also remained constant.

\section{Discussion}

The biphasic appearance of radioactively labeled proteins in bile with a minor peak after 12 minutes and a steep increase after 50 minutes indicates that the majority of plasma proteins in dog bile were derived from serum. A small amount, of serum proteins in bile, however, was secreted by the liver directly into bile. This is compatible with results of experiments performed with rat. 13 out of 16 major proteins of rat bile are derived from serum. Only three proteins are derived from hepatocytes or plasma membranes [7]. Experiments in mice have also shown that albumin in bile predominantly originates from plasma and only a small amount is directly secreted from the hepatocytes into bile [8]. The fact that the serum proteins are delivered into dog bile in the same way as in mice and rat strongly indicates that in humans the proteins are delivered into human bile in the same way.

${ }^{*}$ Correspondence to: Kurt Weigand, Department of Medicine, Stauferklinik, Mutlangen, Teaching Hospital of the University of Ulm, Germany, Tel: 0049717163723; E-mail: k-weigand@t-online.de

key words: dog bile, bile proteins, protein secretion

Received: September 30, 2019; Accepted: October 14, 2019; Published: October 18,2019 


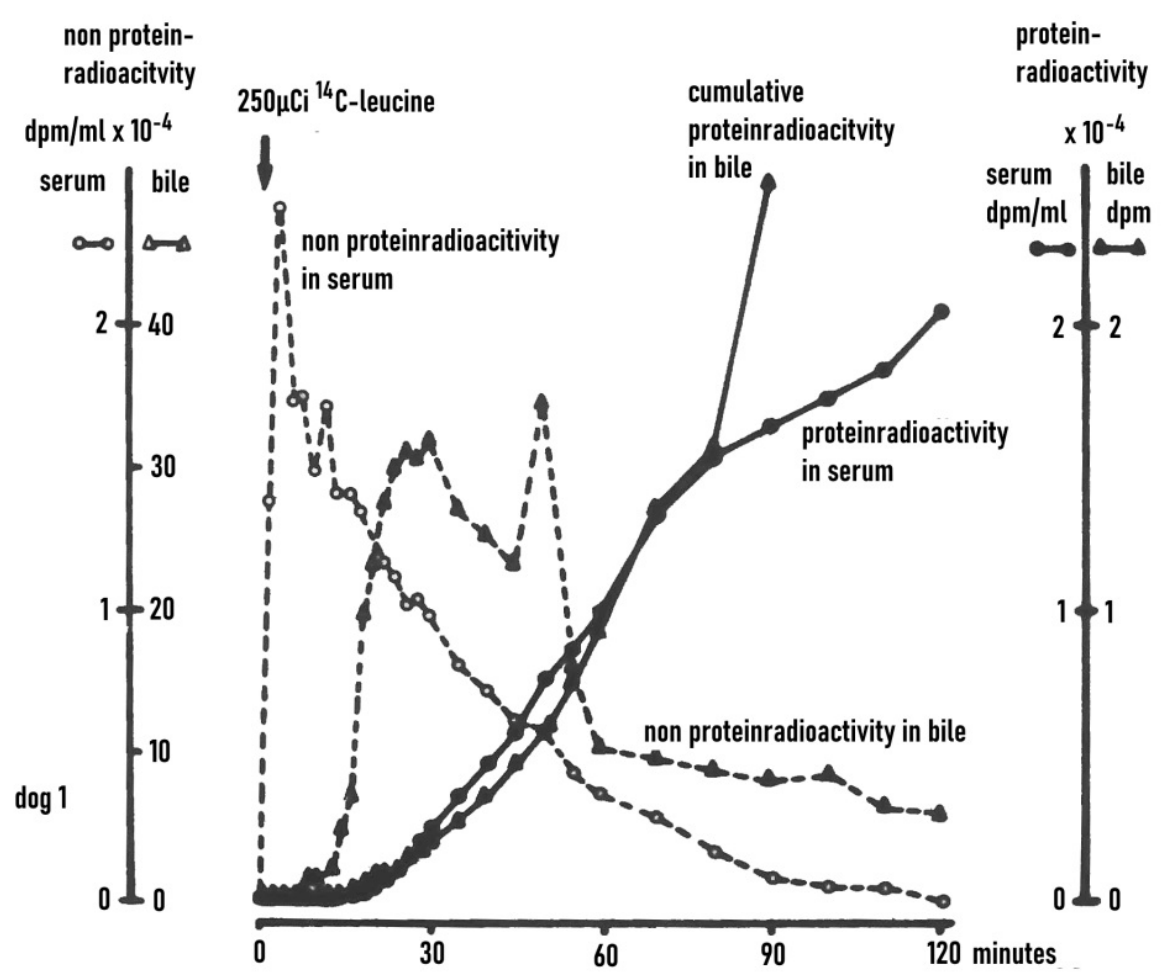

Figure 1. Non protein and protein radioactivity in serum and bile after i.v. injection of 14-C-leucine into dog 1

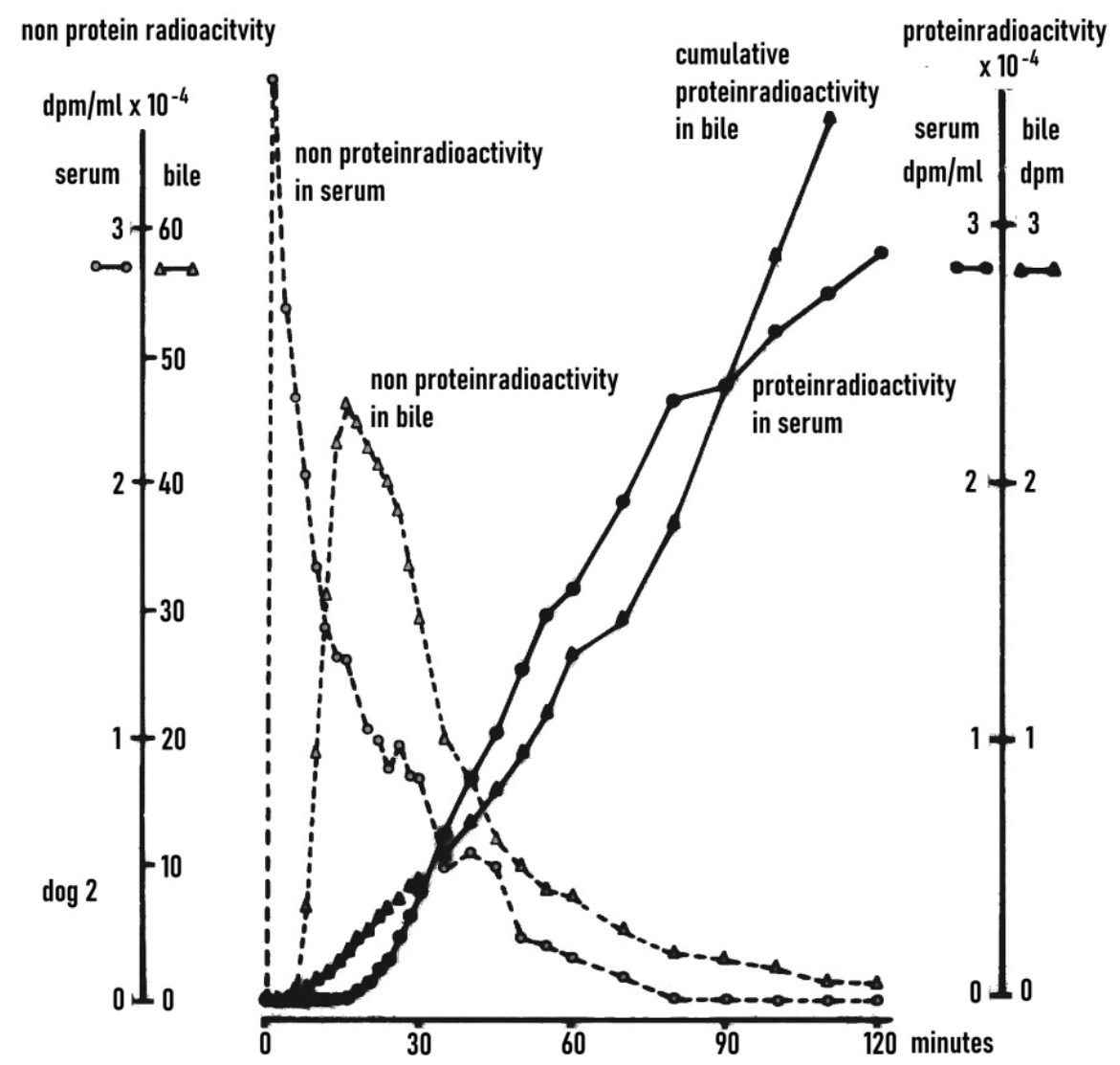

Figure 2. Non protein and protein radioactivity in serum and bile after i.v. injection of 14-C-leucine into dog 2 . 


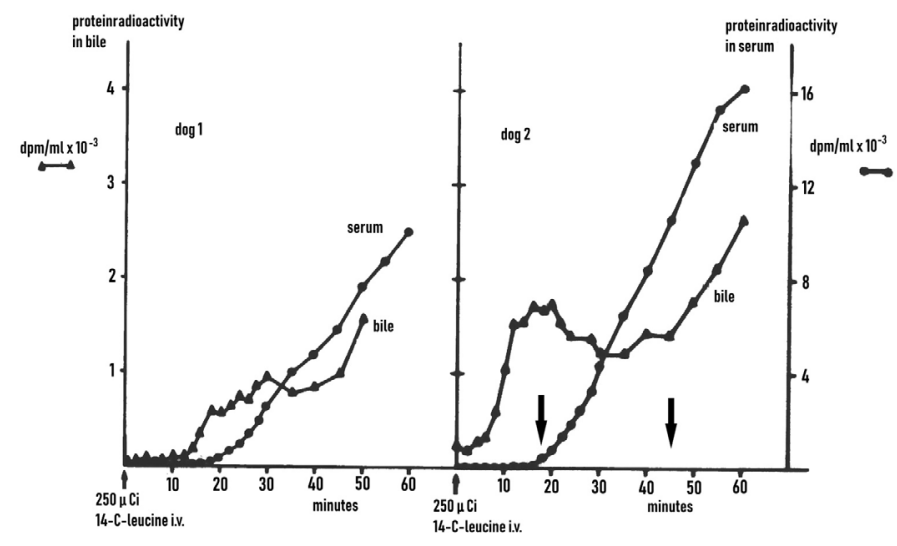

Figure 3. Appearance of radioactively labeled proteins in serum and bile of the dog after i.v. injection of 14-C-leucine.

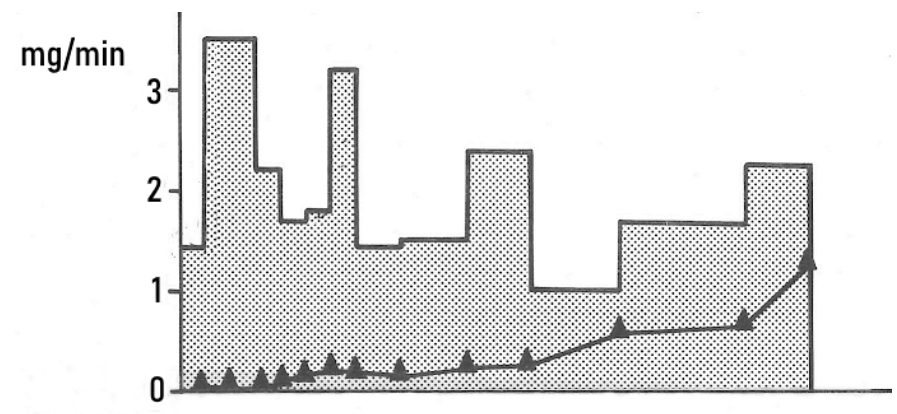

Figure 4. Excretion and specific radioactivity of bile proteins in dog 1

\section{Conclusion}

The secretion time for plasma proteins in the dog is 18-20 minutes. The biphasic appearance of radioactive proteins in bile with a smaller peak after 20 minutes and a steep increase after 45 minutes indicates that the majority of bile proteins are derived from serum, a small amount, however, is secreted by hepatocytes directly into the bile.

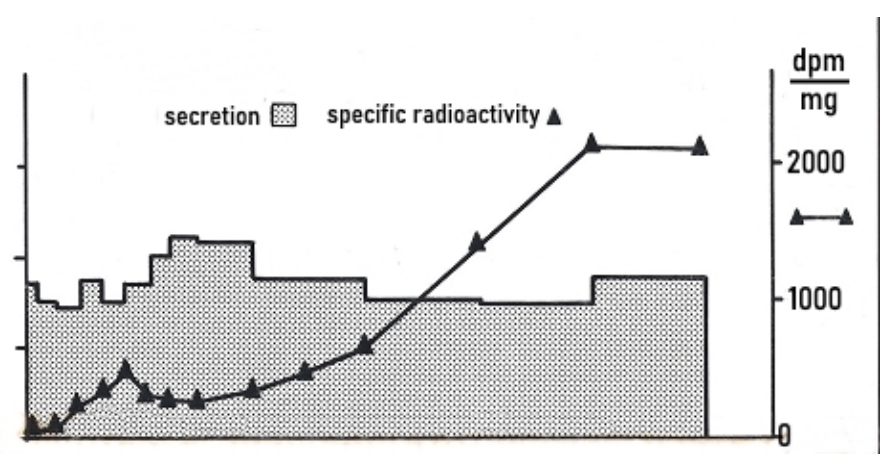

Figure 5. Excretion and specific radioactivity of bile proteins in $\operatorname{dog} 2$

\section{Acknowledgements}

This work was supported by the Swiss National Foundation for Scientific Research.

\section{References}

1. Reuben A (1984) Biliary proteins. Hepatology 4: 46S-50S. [Crossref]

2. La Russo NF (1984) Proteins in bile: how they get there and what they do. Am J Physiol 247: G199-G205. [Crossref]

3. Delacroix DL, Furtado-Barreira G, De Hemptinne B, Goudswaard J, Dive C, et al (1983) The Liver in the IgA Secretory Immune System. Dogs, But Not Rats and Rabbits, Are Suitable Models for Human Studies. Hepatology 3: 980-988.

4. Mans RJ, Novelli GD (1961) Measurement of the incorporation of radioactive amino acids into protein by a filter-paper disk method. Arch Biochem Biophys 94: 48-53.

5. Lowry OH, Rosebrough WJ, Farr AL, Randall RJ (1951) Protein measurement of the incorporation of radioactive amino acids into protein by a filter-paper disc method. $J$ Biol Chem: 193-265

6. Talalay P (1960) Enzymatic analysis of steroid hormones. Biochem Anal 8: 119-143. [Crossref]

7. Mullock BM, Dobrota M, Hinton RH (1978) Sources of the proteins of rat bile. Biochim Biophys Acta 543: 497-507. [Crossref]

8. Groen AK, Van Wijland MJA, Frederiks WM, Smit JJM, Schinkel AH, et al. (1995) Regulation of protein secretion into bile: Studies in mice with a disrupted mdr2 p-glycoprotein gene. Gastroenterology 109: 1997-2006. [Crossref]

Copyright: (C2019 Weigand K. This is an open-access article distributed under the terms of the Creative Commons Attribution License, which permits unrestricted use, distribution, and reproduction in any medium, provided the original author and source are credited. 